\title{
Evaluation of Saltol QTL Introgression in Rice: A Study on Co-Existence of Salinity Tolerance and Phytoremediation Effect
}

\author{
D. Dhivyapriya ${ }^{1 *}$, S. Ramchander ${ }^{1}$, A. Kalamani ${ }^{2}$, M. Raveendran ${ }^{3}$, \\ P. Jeyaprakash ${ }^{1}$ and S. Robin ${ }^{1}$ \\ ${ }^{1}$ Department of Rice, ${ }^{2}$ Department of Forage Crops, Centre for Plant Breeding and Genetics, \\ TNAU, Coimbatore, Tamil Nadu, India \\ ${ }^{3}$ Department of Plant Biotechnology, CPMB \& B, TNAU, Coimbatore, Tamil Nadu, India \\ *Corresponding author
}

\section{A B S T R A C T}

Developing salinity tolerant crop varieties will enable crops to grow in saline soils without compromising yield. Improved White Ponni (IWP) is a salt sensitive rice variety but it is

Keywords

Rice, Improved White Ponni, Saltol, Salinity and Phytoremediation.

\section{Article Info}

Accepted:

04 October 2017

Available Online:

10 December 2017 widely cultivated for its grain quality and yield. Efforts were made to develop salt tolerant Improved White Ponni (IWP) lines by introgressing Saltol QTL from FL478 (Tolerant cultivar) through Marker Assisted Backcross Breeding (MABB). Foreground marker RM3412 was employed to select the positive genotypes harboring Saltol QTL. Under stress condition, $\mathrm{Na}^{+} / \mathrm{K}^{+}$ratio ranged from 0.25 (IWP-10-13-3-20-2-2) to 1.36 (IWP). All the NILs viz., IWP-10-13-3-20-2-2 (0.25), IWP-10-13-3-20-2-5 (0.44), IWP-10-13-3-20-27 (0.42) and IWP-10-13-3-56-2-7 (0.52) recorded $\mathrm{Na}^{+} / \mathrm{K}^{+}$ratio lesser ratio than IWP (1.36). The Near Isogenic Lines (NILs) showed nearly 60 - 84 per cent enhanced level of salinity tolerance compared to susceptible parent Improved White Ponni. This enhanced tolerance of NILs speculates to investigate the mechanism of salinity tolerance in NILs with a hypothesis of that do salinity tolerance and phytoremediation co-exist as two sides of a coin. The study concluded that NILs with Saltol QTL does not had phytoremediation ability but salinity and phytoremediation can coexist if $\mathrm{NHX}$-type $\mathrm{Na}+\mathrm{H}+$ antiporter genes are used to develop salinity tolerant rice genotype.

\section{Introduction}

Soils are classified as saline when the electrical conductivity (EC) is $4 \mathrm{dS} / \mathrm{m}$ or more which is equivalent to approximately $40 \mathrm{mM}$ $\mathrm{NaCl}$ and generates an osmotic pressure of approximately $0.2 \mathrm{MPa}$. This definition of salinity derives from the EC that significantly reduces the yield of most crops (PirastehAnosheh et al., 2016). Salinity is one of the abiotic stresses limiting rice production globally. In India, total salt affected area is reported to be $\sim 8.1$ million ha. In the recent years, salt affected areas are growing at the rate of 10 per cent every year thus making the soil unsuitable for cultivation and thereby rendering crop productivity to decline (Maji et al., 2010). Salinity contribute to the loss of arable lands due to salt accumulation as a result of excessive use of irrigation water with poor or improper drainage, a fact that is likely to be aggravated by sea level rise in coastal areas caused by climate change (Platten et al., 2013). Management of salinity is energy 
intensive agricultural practice hence developing salinity tolerant crop plants is a best strategy to combat salinity. In order to develop salinity tolerant lines of Improved White Ponni (IWP), Saltol QTL on chromosome 1 was transferred from FL478 to IWP using Marker Assisted Backcrossing. The Near Isogenic Lines (NILs) showed an enhanced salinity tolerance compared to susceptible parent Improved White Ponni. The salinity tolerance of NILs over the susceptible parent speculates to investigate the mechanism of salinity tolerance in NILs and to study the phytoremediation effect with the help of hydroponics screening under glass house condition.

\section{Materials and Methods}

Near Isogenic Lines $\left(\mathrm{BC}_{2} \mathrm{~F}_{6}\right)$ viz., IWP-10-133-20-2-2, IWP-10-13-3-20-2-5, IWP-10-13-320-2-7 and IWP-10-13-3-56-2-7 were developed by introgressing salT QTL from FL478 in Improved White Ponni background. Pokkali was used as a check variety. RM3412 was used for foreground selection of positive plants harboring Saltol QTL (Fig. 1). Evaluation of salinity tolerance was carried out under hydroponics using Modified Yoshida Solution in the glass house. The sterilized seeds were placed in petriplates and kept at $27^{\circ} \mathrm{C}$ for germination.

\section{Making floats for seedling growth under hydroponic conditions}

Rectangular thermocole sheets of size $38 \times 26$ $\times 1.5 \mathrm{~cm}$ were used to make floats for seedling growth. Holes of $1.5 \mathrm{~cm}$ diameter were made in the thermocole sheet with spacing of $4.2 \times 2.8 \mathrm{~cm}$. A tray of size $38 \times 26$ with 15 liters of water holding capacity was selected to accommodate seedling floats (Fig. 2). Salinity stress was imposed after well establishment of seedlings (10 days after transfer to seedling floats) under hydroponics culture conditions. The nutrient media was salinized by dissolving $5.84 \mathrm{~g} \mathrm{NaCl}$ per litre of the medium to get $100 \mathrm{mM}$ concentration of $\mathrm{NaCl}$. The $\mathrm{pH}$ was monitored daily and adjusted to 4.5. Control plants were maintained without salinity stress. Three replications were maintained for control and stress.

\section{Estimation of sodium and potassium content in leaves}

Sample for sodium and potassium estimation was collected when the susceptible parent showed salinity stress symptom. Sodium and potassium content of the sample were analysed using Flame Photometer (ELICO, Model CL-361) following triple acid $\left(\mathrm{HNO}_{3}\right.$, $\mathrm{H}_{2} \mathrm{SO}_{4}$ and $\mathrm{HClO}_{4}$ in the ratio of 9:2:1) digestion of the samples (Yoshida et al., 1976). The sodium and potassium content was expressed in $\mathrm{mg} / \mathrm{g}$ of sample on dry weight basis. Sodium and potassium content of leaves, stem and roots were estimated separately and summed up to arrive the total sodium and potassium content. Sodium potassium ratio was calculated by dividing the total sodium content by total potassium content.

\section{Results and Discussion}

The ability of plants to accumulate ions in the plant parts results in the depletion of ions in the growing medium provided if the ions are not replenished by natural or artificial means. This phenomena develops an insight to dissect the salinity tolerance in rice can coexist with phytoremediation. Genetic variability for salinity tolerance was observed in rice and the mechanism of salinity tolerance varies depending up on the nature of gene/s governing the salinity tolerance (Platten et al., 2013). Sodium/potassium ratio was considered to be a reliable parameter used to evaluate salt tolerance ability of rice cultivars (Gregorio et al., 1997). 
Under stress condition, total sodium content ranged from $29.97 \mathrm{mg} / \mathrm{g}$ (IWP-10-13-3-20-22) and $83.13 \mathrm{mg} / \mathrm{g}$ (IWP) with a mean of $39.23 \mathrm{mg} / \mathrm{g}$. All the NILs viz., IWP-10-13-320-2-2 (29.97 mg/g), IWP-10-13-3-20-2-5 (32.70 $\mathrm{mg} / \mathrm{g}), \quad$ IWP-10-13-3-20-2-7 (32.95 $\mathrm{mg} / \mathrm{g}$ ) and IWP-10-13-3-56-2-7 (31.74 $\mathrm{mg} / \mathrm{g}$ ) showed lower sodium content than IWP $(83.13 \mathrm{mg} / \mathrm{g})$ (Table 1). The lower sodium content in NILs clearly indicates that these plants have sodium exclusion strategy to maintain ion homeostasis rather than sodium sequestration in the vacuole. Similar phenomena were observed in FL478 and Pokkali (Arunroj et al., 2005). This phenomenon is further confirmed by considering the potassium content and also by sodium/ potassium ratio $\left(\mathrm{Na}^{+} / \mathrm{K}^{+}\right)$. In stress condition, $\mathrm{Na}^{+} / \mathrm{K}^{+}$ranged from 0.25 (IWP-1013-3-20-2-2) to 1.36 (IWP). All the NILs viz., IWP-10-13-3-20-2-2 (0.25), IWP-10-13-3-202-5 (0.44), IWP-10-13-3-20-2-7 (0.42) and IWP-10-13-3-56-2-7 (0.52) recorded lesser ratio than IWP (1.36). Similar pattern of sodium and potassium content was observed in control except for the magnitude of the content.

Among the NILs, the percentage of sodium content is higher in IWP-13-3-30-2-7 with $31.95 \%$ whereas the lowest one is observed in the NIL IWP-13-3-30-2-2 with $28.97 \%$. The percentage of potassium content is higher in the IWP-13-3-30-2-5 with $-0.15 \%$, the lowest is IWP-13-3-56-2-7 with -0.44\%. Percentage of Sodium/potassium ratio is higher in IWP-13-356-2-7 (4.20\%) and the lowest was observed in IWP-13-3-30-2-2 (1.77\%). The percentage of enhanced level of salinity tolerance was observed maximum for the BIL IWP-13-3-302-2 with 84 per cent. Other Near Isogenic Lines viz., IWP-13-3-30-2-5, IWP-13-3-30-2-7, IWP-13-3-56-2-7 showed 73\%, 75\% and 63\% enhanced level of salinity tolerance compared to susceptible parent Improved White Ponni respectively.

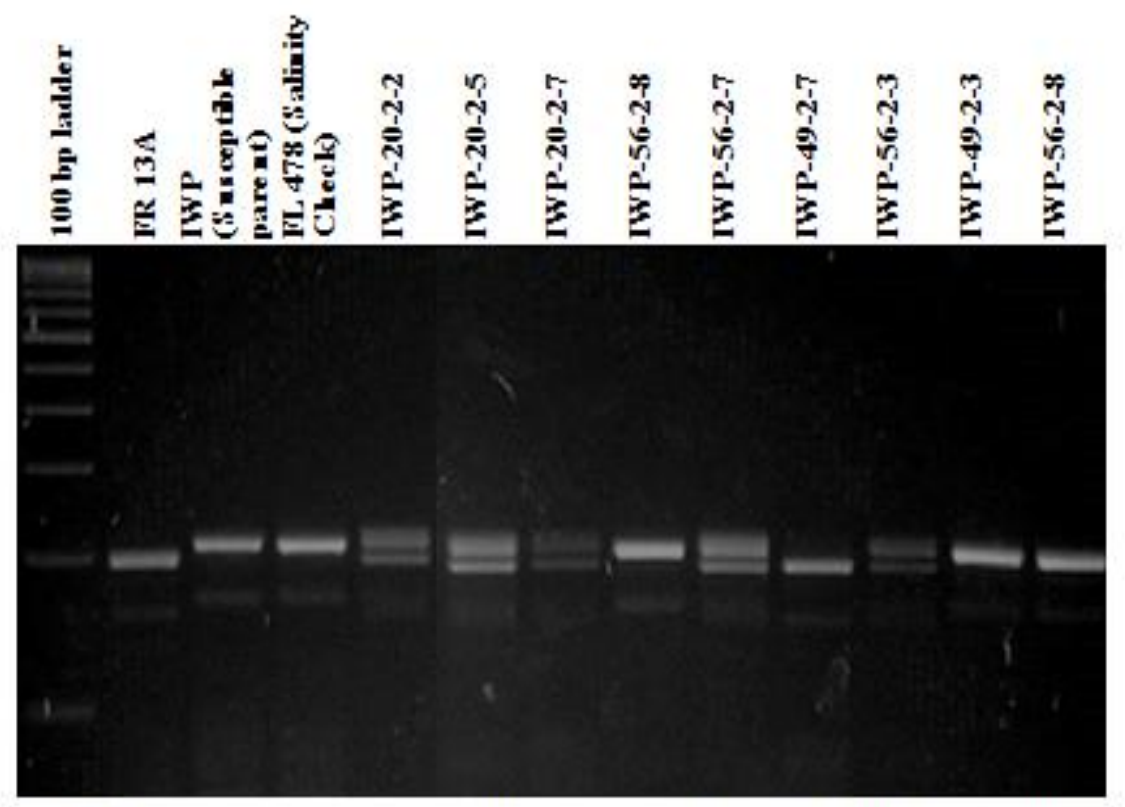

Fig. 1 Foreground selection of salinity tolerant BILs using RM3412. FRl3A parent is given as these NILs also contains Sub1 QTL, but for selecting salinity tolerant BILs FRl3A will be ignored only FL478 will be considered. IWP-20-22, IWP-20-2-5, IWP-20-2-7 and IWP-56-2-7 was selected for evaluation. 
Fig.2 Screening of parents (NILs) against salinity stress

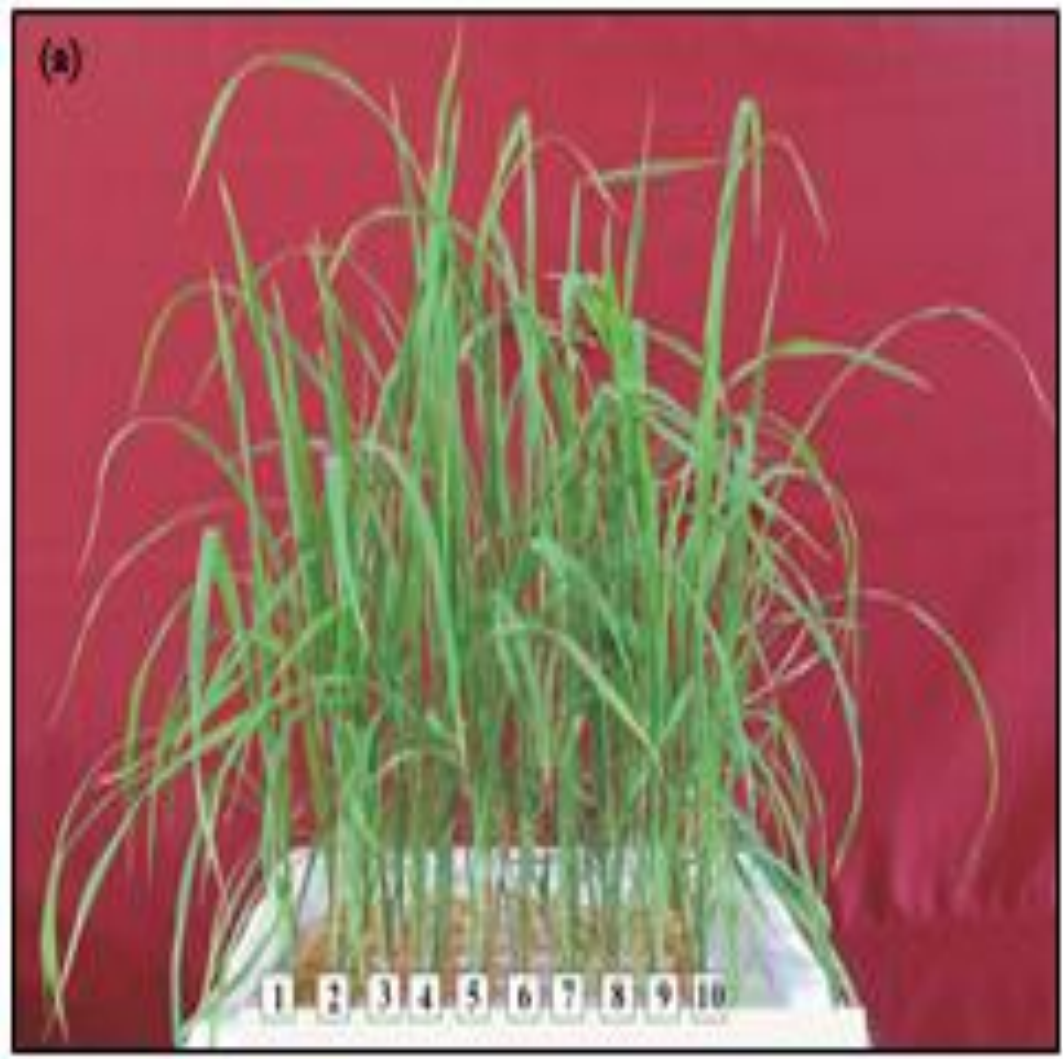

\begin{tabular}{|c|c|}
\hline \multicolumn{2}{|c|}{ (a) Before imposition of stress } \\
\hline \multicolumn{2}{|c|}{ (b) After imposition of stress (100 mM NaCl) } \\
\hline 1) IWP & 6) Pokkali \\
\hline 2) IWP- 10-13-3-20-2-2 & 7) FL478 \\
\hline 3) IWP-10-13-3-20-2-5 & 8) Pokkali \\
\hline 4) IWP-10-13-3-20-2-7 & 9) FL478 \\
\hline 5) IWP-10-13-3-56-2-7 & $\begin{array}{l}\text { 10) IWP- 10-13-3- } \\
20-2-2\end{array}$ \\
\hline
\end{tabular}

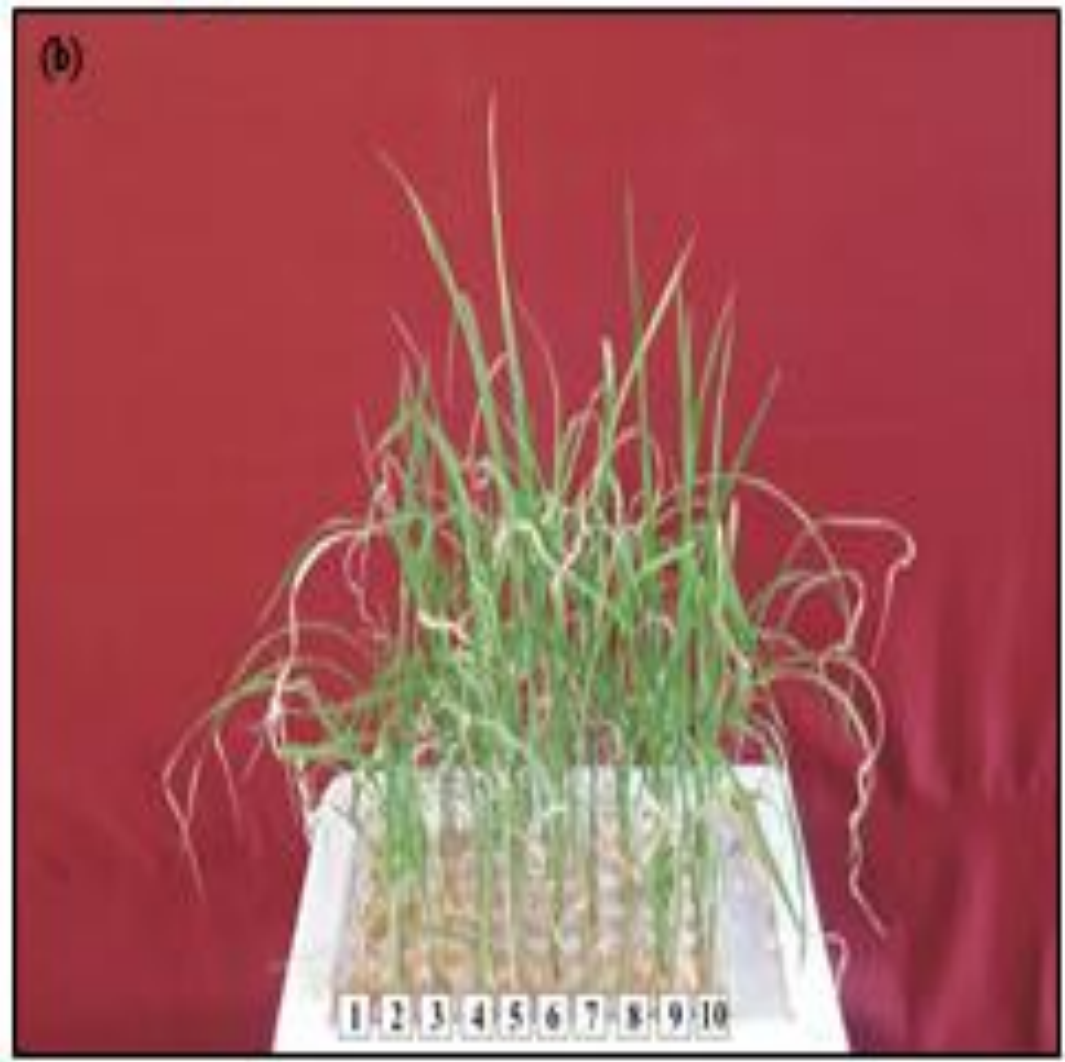


Table.1 Sodium, potassium and sodium potassium ratio of NILs along with along with tolerant (FL478) and susceptible parent (IWP) under control and salinity stress condition $(100 \mathrm{mM} \mathrm{NaCl})$ [* Significant at 0.05 per cent probability]

\begin{tabular}{|c|c|c|c|c|c|c|c|c|c|}
\hline \multirow[t]{2}{*}{ Genotypes } & \multicolumn{2}{|c|}{$\begin{array}{l}\text { Sodium content } \\
\left(\mathrm{Na}^{+}\right)(\mathbf{m g} / \mathbf{g})\end{array}$} & \multirow{2}{*}{$\begin{array}{c}\% \text { of } \\
\mathrm{Na}+ \\
\text { content } \\
\text { over } \\
\text { control }\end{array}$} & \multicolumn{2}{|c|}{$\begin{array}{l}\text { Potassium } \\
\text { content }\left(\mathbf{K}^{+}\right) \\
(\mathbf{m g} / \mathbf{g})\end{array}$} & \multicolumn{2}{|c|}{$\mathrm{Na}^{+} / \mathrm{K}^{+}$ratio } & \multirow[t]{2}{*}{$\begin{array}{l}\% \text { of } K+ \\
\text { content } \\
\text { over } \\
\text { control }\end{array}$} & \multirow[t]{2}{*}{$\begin{array}{c}\% \text { of } \mathrm{Na}^{+} / \mathrm{K}^{+} \text {ratio } \\
\text { Content over } \\
\text { control }\end{array}$} \\
\hline & Control & Stress & & Control & Stress & Control & Stress & & \\
\hline IWP-13-3-20-2-2 & 13.83 & $29.97 *$ & 28.97 & $161.17 *$ & $121.58 *$ & $0.09 *$ & $0.25^{*}$ & -0.24 & 1.77 \\
\hline IWP-13-3-20-2-5 & 12.21 & 32.70 & 31.70 & 106.98 & 74.50 & 0.11 & 0.44 & -0.30 & 3.00 \\
\hline IWP-13-3-20-2-7 & $10.22 *$ & 32.95 & 31.95 & 93.78 & 79.02 & 0.11 & 0.42 & -0.15 & 2.81 \\
\hline IWP-13-3-56-2-7 & 11.45 & $31.74 *$ & 30.74 & 110.14 & 61.35 & $0.10 *$ & 0.52 & -0.44 & 4.20 \\
\hline IWP & $11.07 *$ & 83.13 & 82.13 & 102.97 & 61.28 & 0.11 & 1.36 & -0.40 & 11.36 \\
\hline Pokkali & $10.59 *$ & 32.55 & 31.55 & 100.84 & $112.93 *$ & 0.11 & $0.29 *$ & 0.11 & 1.63 \\
\hline FL478 & 11.86 & $31.55^{*}$ & 30.55 & 100.61 & $111.78 *$ & 0.12 & $0.28 *$ & 0.11 & 1.33 \\
\hline Mean & 11.61 & 39.23 & & 110.93 & 88.92 & 0.107 & 0.51 & & \\
\hline SE & 0.45 & 7.33 & & 8.60 & 9.75 & 0.004 & 0.15 & & \\
\hline
\end{tabular}


The IWP absorbs more sodium from the salinized growing medium but unable to sequestrate inside the vacuole hence high cytosolic $\mathrm{Na}^{+}$impaired the cellular activity. But the salinity tolerant NILs maintains low cytosolic $\mathrm{Na}^{+}$due to the fact that Saltol affect the $\mathrm{Na}^{+} / \mathrm{K}^{+}$through the sodium transporter SKC1 the causal gene underlying the Saltol QTL (Thomson et al., 2010). SKCl was found to encode a sodium transporter that helps control $\mathrm{Na}+\mathrm{K}+$ homeostasis through unloading of $\mathrm{Na}^{+}$from the xylem (Ren et al., 2005), which has been suggested to function primarily in roots to reduce the amount of $\mathrm{Na}^{+}$ions that are transported to the leaves (Hauser and Horie 2010). Moreover functional annotation of 14 genes within Saltol QTL has been reported (Soda et al., 2013). None of the gene related to sodium sequestration process. This clearly indicates that Saltol introgressed NILs does not have phytoremediation capacity.

Molecular and functional analyses of rice NHX-type $\mathrm{Na}^{+} / \mathrm{H}^{+}$antiporter genes revealed the important role of this gene in the compartmentalization of $\mathrm{Na}^{+}$into vacuoles (Fukuda et al., 2011). With the advent of Next Generation Sequencing technologies the donor which has the highest expression of $\mathrm{Na}^{+} / \mathrm{H}^{+}$antiporter genes can be identified and the same can be utilized to develop salinity tolerant rice genotypes with phytoremediation capacity by molecular breeding. Salinity tolerant genotypes with phytoremediation capacity will be an added advantage. In addition to grain yield, salinity tolerant rice genotypes with phytoremediation capacity ensures the reduced salinity levels in soil with subsequent cultivation of crops there by increasing the percentage of arable land.

Salinity tolerant NILs introgressed with Saltol QTL does not have any phytoremediation activity. But, developing plants with $\mathrm{Na}^{+} / \mathrm{H}^{+}$ antiporter genes would ensure salinity tolerance along with phytoremediation of sodium from the soil but this strategy should be further confirmed by experimental procedures.

\section{Acknowledgement}

The authors are grateful to the Department of Biotechnology, Government of India (New Delhi) for their financial assistance to undertake this investigation on "Marker Assisted introgression of different traits to develop New Generation Rice varieties".

\section{References}

Arunroj, S. D., N. Supapoj, A. Vanavichit and T. Toojinda. 2005. Screening and selection for physiological characters contributing to salinity tolerance in rice. Kasetsart J. Nat. Sci., 39(2): 174-185.

Fukuda, A., Nakamura, A., Hara, N., Toki, S. and Tanaka, Y. 2011. Molecular and functional analyses of rice NHX-type $\mathrm{Na}^{+} / \mathrm{H}^{+}$antiporter genes. Planta. 233(1):175-188.

Gregorio, G. B., Senadhira, D. and Mendoza, R. D. 1997. Screening rice for salinity tolerance. IRRI Discussion Paper Series no. 22. International Rice Research Institute, Manila (Philippines): 1-30.

Hauser, F. and Horie, T. A. 2010. Conserved primary salt tolerance mechanism mediated by HKT transporters: a mechanism for sodium exclusion and maintenance of high $\mathrm{K}+/ \mathrm{Na}+$ ratio in leaves during salinity stress. Plant Cell and Environ. 33: 552-565.

IRRI. 2014. Standard evaluation system for rice (SES), 5th edition. Los Baños, Philippines.

Maji, A., Reddy, G. and Sarkar, D. 2010. Degraded and wastelands of India: Status and spatial distribution. Indian Council of Agric. Res., New Delhi, pp.167.

Pirasteh-Anosheh, H., Ranjbar, G., Pakniyat, 
H. and Emam, Y. 2016. Physiological mechanisms of salt stress tolerance in plants: An overview. In PlantEnvironment Interaction: Responses and Approaches to Mitigate Stress, Azooz, M. M. and Ahmad, P. (Eds.), John Wiley \& Sons, UK. pp. 141-160.

Platten, J. D., Egdane J. A. and Ismail, A. M. 2013. Salinity tolerance, $\mathrm{Na}^{+}$exclusion and allele mining of HKT1; 5 in Oryza sativa and $O$. glaberrima: many sources, many genes, one mechanism? BMC Plant Biol. 13: 32.

Ren, Z. H., Gao, J. P., Li, L. G., Cai, X. L., Huang, W., Chao, D. Y., Zhu, M. Z., Wang, Z. Y., Luan, S. and Lin, H. X. 2005. A rice quantitative trait locus for salt tolerance encodes a sodium transporter. Nature Genet. 37: 11411146.
Soda, N., Kushwaha, H. R., Soni, P., SinglaPareek, S. L. and Pareek, A. A. 2013. Suite of new genes defining salinity stress tolerance in seedlings of contrasting rice genotypes. Funct Integr Genomics. 13:351-365.

Thomson, M. J., Ocampo, M. D., Egdane, J., Rahman, M. A., Sajise, A.G., Adorada, D.L., Tumimbang-Raiz, E., Blumwald, E., Seraj, Z.I., Singh, R.K., Gregorio, G.B. and Ismail, A. M. 2010. Characterizing the Saltol Quantitative Trait Locus for Salinity Tolerance in Rice. Rice. 3:148-160.

Yoshida, S., Forno, D. A., Cock, J. H. and Gomez. K. A. 1976. Laboratory manual for physiological studies of rice. (3rd edition) IRRI. Philippines. pp. 83.

\section{How to cite this article:}

Dhivyapriya, D., S. Ramchander, A. Kalamani, M. Raveendran, P. Jeyaprakash and Robin, S. 2017. Evaluation of Saltol QTL Introgression in Rice: A Study on Co-Existence of Salinity Tolerance and Phytoremediation Effect. Int.J.Curr.Microbiol.App.Sci. 6(12): 303-309. doi: https://doi.org/10.20546/ijcmas.2017.612.036 